\title{
An Error Analysis of English Plosive and Fricative Consonants at Vocational High Schools
}

\author{
Febby Pratama Putra
}

Fakultas Ilmu Pendidikan dan Pengetahuan Sosial Universitas Indraprasta PGRI

e-mail : febby.1988@gmail.com

\author{
Cara Sitasi: \\ Putra, F. P. (2019). An Error Analysis of English PlosivE and Fricative Consonants at Vocational \\ High Schools. Wanastra, 11(2), 141-150.
}

\begin{abstract}
The purpose of the research is to analyze plosive and fricative consonants pronunciation errors in recordings that made by students in vocational high school in Jakarta. The research method that used to analyze plosive and fricative consonants pronunciation errors in recordings that made by the students is descriptive qualitative method and based only on a few sound recordings. After the researcher analyzes the recordings, the researcher then found that the students still make the errors in pronouncing the words containing plosive and fricative consonants. The students' most pronunciation errors occur on pronouncing some of the consonants. The students do most errors of pronouncing consonants because they are not familiar on how they should be pronounced, and also the cause of students' pronunciation errors is the different sound between English and Indonesian. Most of students make errors in plosive consonants for about $36 \%$ in total and for the errors $64 \%$ in fricative consonants.
\end{abstract}

Keywords: Errors, Pronunciation, Pronunciation Error

\section{INTRODUCTION}

English is available and accessible to Indonesian students through media such as television, the Internet and through various other forms of another media in society. Because of this constant exposure in society, students are to some extent aware of how the language should sound. Exposure to and awareness of variations such as dialects and accents are reoccurring goals in the Indonesian syllabus for English, meaning that these skills should be worked with on a regular basis in the classroom. One of the general objectives for foreign language teaching and learning is to teach the learner to be mastered in oral or written communication in the target language they learn. Despite this exposure, various language mistakes are usually apparent during the early stages of language acquisition if one enters an L2 language classroom in Indonesia. Difficulties in pronunciation seem to be a problem for many teachers of a foreign language.

In Indonesia there are many problems that learners have when they deal with the pronunciation. Most of the learners have problems when they learn oral skill. It is need to have other skill by people to be mastered in speaking such as grammar competence, listening skill, vocabulary mastery and good pronunciation. Foreign language instruction generally focuses on four main areas of development: listening, speaking reading and writing. Foreign language curricula emphasize pronunciation in the first year of research as it introduces the target language's alphabet and sound system, but rarely continues this focus past the introductory level. One of the key requirements for language proficiency is to secure understandable pronunciation for the language learners. Teachers must act as - pronunciation coaches and learners must be proactive learners taking the initiative to learn.

Pronunciation becomes the most important thing in English communication because mispronuncing caused misunderstanding. For example is between the word "by", "buy", "bye" that has different meaning though the sound is almost the same. It is very common that many foreign language learners have problems in teaching and learning process. In this case, many of 
English foreign learners have difficulties in pronunciation teaching process because of some factors. There are so many local languages in Indonesia. That is why it is difficult to teach pronunciation because the students are varied and they are all influenced by their own mother tongues. In this point, clear and correct pronunciation affects to the process of delivering messages.

Learning and errors are unity packaging that takes place naturally in learning process of foreign language. It is influenced by learners who has different language background depends on where they were born. Every background can influence their first language which since they were child they have been speaking as their mother tongue. Usually, their old habit of speaking has been deeply rooted in them until they are adult. Moreover, that it has set their speech organ to produce the speech sound of native language. The learners, afterwards, take less care of their background speech organ which it is commonly become the main reason of errors in pronunciation..

Perhaps the most surprising finding in L2 acquisition research concerns the errors second language learners make. For several decades, linguists and teachers assumed that most second language learners' errors resulted from differences between the first and second languages..

\section{a. The Nature of Error}

An error is different from mistake, so it is crucial to differentiate both of them. Errors occur for many reasons. One obvious cause is (1) interference from the native language. A learner may make errors because they assume that the target language and their native language are similar, when in fact both of them are different. This kind of overgeneralization is also the cause of many mistaken guesses. Another obvious cause is (2) simply an incomplete knowledge of the target language. A third common cause of error is (3) the complexity of the target language. Certain aspects of English (e.g. the "s" in the third person singular present tense) are difficult for all students, no matter what their native language.

Corder as quotes by Kinsela (1978:63) states that "an error is typically produced by people who do not yet fully command some institution a listed language system". Based on Corder (1973:257), "errors are breaking the role, due to lack of competence such as knowledge of the language, which may or may not be conscious. As they are due to lack of competence, they tend to be not correctable."

In other words, a mistake is a slip that the learner can self-correct whereas an error is what a learner cannot self-correct. From those definitions above, the writer can also conclude that a mistake is just a slip that the learner forgets the right form. It means that, an error is a deviation made by the learner because he or she did not know the rule and thus will make it repetitively.

To distinguish between an error and mistake, Erdogan (2005:263) also suggest two ways, it says "The first one is to check the consistency of learner's writing, if he sometimes uses the correct form and sometimes the wrong one, it is a mistake. However, if he always uses it incorrectly, it is an error. The second way is to ask learner to try to correct his own deviant utterence. When he is unable too, the deviations are errors, while he is successful, they are mistake."

Indeed, learners often make mistakes in the process of foreign language learning. Thus, it is still not a big deal when the learners commit the mistake either in speaking or writing since they are capable to correct the mistake. However, learning other language becomes difficult since the target language has different system from the native language. This difference sometimes makes the learners make errors especially in applying vowel or consonants.

\section{b. The Nature of Error Analysis}

To observe, analyze and classify the errors made by students, error analysis is important to do. Richards (2000:96) says that error analysis is the study of errors made by the second and foreign language learners. Error analysis may be carried out in order to (a) find out how well someone knows a language, (b) find out how a person learns a language, and (c) obtain information on common difficulties in language learning, as an aid in teaching or in the preparation of teaching materials. 
According to Crystal in Hasyim (2002: 42), in language teaching and learning, error analysis is technique for identifying, classifying and systematically interpreting the mistakes made by someone learning a foreign language, using any of the principles and procedures provided by linguistics. Error analysis is a type of linguistic analysis that focuses on the errors that learners make. It consists of a comparison between the errors made in the Target Language (TL) and that TL itself. The investigation of errors can be at the same time diagnostic and prognostic. It is diagnostic because it can tell us the learner's state of the language at a given point during the learning process and prognostic because it can tell course organizers to reorient language learning materials on the basis of the learners' current problems.

Corder (1981: 70) identified a model for error analysis which included three stages:

\section{a. Data collection}

Errors identification of samples is done after the samples are accumulated.

\section{b. Description}

Classify the result of errors identification based on the sources.

\section{c. Explanation}

Explain the evaluation the errors based on comparison of standard features.

In foreign language teaching, error analysis becomes useful device to know the ability of students in language mastery. Errors provide feedback to teacher about the effectiveness of a teaching materials and teaching techniques. According to Carl James (2013: 15-20) there are procedures to analyze data in error analysis that consist of:

\section{a. Identification of errors}

In identifying errors the sentences that produced by students are compared with the normal and correct sentences in the target language .

\section{b. Describing error}

In this step, the errors are classified into word order categories relating to the distribution of noun phrase in sentence or construction of sentence. Beside that, describing error is to identify the differences of disordering of word between students' utterances and the reconstructed of target language utterances

\section{c. Explanation of errors}

Explaining is a step to analyze the cause of errors.In other words, in this step the writer tries to explain how and why a sentence called to be erroneous.

\section{d. Evaluation of errors}

Evaluation is a process to collects, clarifies and verifies relevant values and standard. It is designed to reduce, revised and devise remedial lessons in teaching learning process. However, in this research, the writer uses evaluating the errors as a step that involves drawing conclusion.

\section{c. The Nature of Pronunciation}

\section{Consonant}

Underhill (2005:29) explains consonant into two meanings. The first meaning of consonant is the sounds which are made by restricting or blocking the air flow in some physical way, and this restriction which makes the consonant its characteristic sound. The second meaning is consonant marks the beginning and end of syllable.

\section{1) Force of articulation (voicing)}

In his book, Kelly (2000:47) says force of articulation describes the consonants in term of the breath force. Underhill (2005:30) says there are two kinds of consonants in force of articulation (voicing) category. They are voiced and unvoiced. Voiced consonants need the vocal cords to vibrate, while the unvoiced do not need the vocal cords to vibrate.

The difference between voiced or unvoiced tends to deal with soft and strong aspiration because of its need to take the energy from the breath to drive the larynx. Partly the voiced consonants are sounded with softer breath force. On the other hand, the unvoiced consonants are sounded with stronger breath force. This is because its sounds need to balance their lack of voice with force and distinction in their articulation. 
2) Place of articulation.

The manner of articulation refers to how the air stream is modified by the vocal tract to produce the sound depends on the degree of closure of the articulation, that is, how close together of how far a part they are. Seven manners of articulation that are:

\section{a. Stops}

Stops are sounds which are produced by stopping the air somewhere in the mouth or vocal passage and releasing it suddenly. When saying /p/ and /b/ the lips are closed together for a moment, stopping the air flow. $/ \mathrm{p} /$ and $/ \mathrm{b} /$ are bilabial stops; $/ \mathrm{p} /$ is a voiceless bilabial stop and $/ \mathrm{b} /$ is a voiced bilabial stop. The other consonants are $/ \mathrm{t} /$, /d/, /k/, /g/.

\section{b. Affricates}

Affricates are sounds which are made up of two parts; a stop and a fricative. They are made by briefly stopping the air stream completely and then releasing the articulators slightly so that friction is produced. English has only two affricates: $/ \mathrm{t} /$ and $/ \mathrm{d} / \mathrm{s}$.

\section{c. Fricatives}

Fricatives are sounds which are made by forming a nearly complete stoppage of the air stream. The opening through which the air escapes is so small that friction is produced. The fricative consonants are /f, $\mathrm{v}$, $\ominus$, ठ, s, $\mathrm{z}, \int, \mathrm{z}, \mathrm{h} /$.

\section{d. Nasals}

Nasal are sounds which are produced with the air going out through the nose or nasal cavity. When you make a nasal sound, the soft palate is lowered so that air escapes through the nose. Nasal consonants are normally voiced. English has a bilabial, an alveolar, and a velar nasal, represented by the symbols /m, n, $\mathrm{y} /$.

\section{e. Lateral}

Laterals are sounds are produced by having air go out of the mouth from the both sides of the tongue. Laterals are normally voiced. English have the only lateral is the alveolar lateral /1/.

f. Semi - vowels
Semivowels are sounds which are considered half consonant and half vowels. They are like consonants in their structural behavior, and they are like vowels in their quality. The semivowels are /w/ and /y/ as in the words win and yes.

\section{1) Vowel}

Vowel is the words which pronounced with air flow freely, shape of vocal tract is altered to create different sounds. Here is the IPA (International Phonetic Alphabet) table of vowel:

- Close vowel: the tongue position is high in the mouth. The close vowels are /i:/, /I/, /u:/ and $/ \mho /$.

- Mid vowel: the tongue position is in the middle of mouth. The mid vowels are /e/, /a/, /3:/ and /o:/.

- Open vowel: the tongue position is low in the mouth. The open vowels are $/ \mathfrak{x} /, / \Lambda /$, /a:/ and $/ \mathrm{p} /$. While pure vowel is a single vowel, diphthong is a combination of vowels' sound. There is a glide when pronouncing one pure vowel to another vowel. English has eight diphthongs which are divided into two categories.

- Centering diphthong: this is the diphthong with $/ \mathrm{a} /$ at the end. It is called centering because $/ \partial /$ is center vowel. The examples are /I ə/, / $/$ ə/ and /e ə/.

- Closing diphthong: this is the diphthong with $/ \mathrm{I} /$ and $/ \mathrm{\sigma} /$ at the end. The examples are /eI/ in the word they, /oI/ in the word boy, /aI/ in the word mighty, /ov/ in the word go and /av/ in "now"

\section{RESEARCH METHODOLOGY}

The writer uses a qualitative approach in this research paper. This type of the research does not apply the detail arithmetic calculation or statistic. It contains sentences or description of the objects. It refers to the meanings, concepts, definitions, characteristics, metaphors, symbols, and descriptions of things.

Some considerations that the researcher used to take sample in this research are as follows: 
1. The subjects which taken as the sample in this research should be $2^{\text {nd }}$ grader of vocational high school students.

2. Their specialities must be close to English subject.

\section{Data Collecting Technique}

There are many ways to collect the data such as: documentation, observation, test, interview and questionnaire. In this case the writer uses voice recording as the way to collect the data.

The writer analyzed the recordings assignment to collect the data which related with this research. For collecting the data, the writer run observation through these steps as follows:

a) Listening the recording of the students.

b) Transcribing the recording.

c) Classifying the errors in the data.

The technique which is used in collecting the data, the writer used test technique as a resource. The test material was not given directly to the learner but only the material given. The data collected is in a form of audio files of students recording, within its topic about consonant especially plosive and fricative consonant. Students record their voice through an application called Davitech Teacher or DVR, and then the succesful recorded voice were taken into computer server. The lecturer then analyze the errors found in the recording.

\section{The Research Variable}

The research variable in this research will discuss about the pronunciation process of plosive or stop consonant $(\boldsymbol{p}, \boldsymbol{b}, \boldsymbol{k}, \boldsymbol{g}, \boldsymbol{t}$, and $\boldsymbol{d}$ ) and fricative consonants $\left(\boldsymbol{f}-\boldsymbol{v}, \boldsymbol{\theta}-\boldsymbol{\partial}, \boldsymbol{s}-\boldsymbol{z}, \boldsymbol{\int}\right.$ - 3, and $\boldsymbol{h}$ ) pronounced by $2^{\text {nd }}$ grader of vocational high school students in Jakarta. The way they are pronouncing the consonants may be confusing because there are rhymes, air, and intonation that specifically used in the consonant. Usually, there are minimal pairs test to conduct if there are errors in the pronuncing the plosive, for example in $/ \mathrm{p} / \mathrm{mop}$ and $/ \mathrm{b} / \mathrm{mob}$.
Based on the background of the problem that has described above the problem which can identify are (1) kinds of consonants often mispronounced, (2) alteration features pronounced by the students, (3) errors mostly found in students, (4) the causes of errors, (5) difficulties happened during teaching pronunciation process, (6) the common characteristics of pronunciation error, (7) the influence of Bahasa in pronunciation error.

Because there are many problems occur in teaching and learning process, particularly in students' speaking skill, the writer limits the problems into:

1. To analyze the plosive and fricative consonants which are often mispronounced by the students

2. To identify the problems faced by students that they make error in pronunciation.

3. To find out the most dominant errors in pronunciation made by the students

This research is aimed to examine, to analyze, and to find out the errors mostly found when pronuncing plosive consonants and to identify the causes of errors which the students made.

\section{FINDING AND RESULT}

The subjects in this research are the recordings of students. The researcher analyzes one class from each school so that means there are two classes. There are 70 students that analyzed and random samplings are used in taking the samples. In this research, the researcher took about 50 samples of recordings, 25 samples from SMK MUHAMMADIYAH and 25 samples from SMK PGRI 5. The research is done by analyze the errors that done by the students. There are two types of wordlists that used in the recording. The first one is minimal pair words and the other is wordlist based on plosive and fricative types. The students are free to choose which words they desired because the point is to analyze the errors in pronouncing the plosive and fricative words.

Here is list of words which students do error pronunciation in the recording: 
Table 1. Plosive error

\begin{tabular}{|c|c|c|}
\hline No & Word & Sound \\
\hline 1 & Card & $/ \mathrm{ka}: \mathrm{d} /$ \\
\hline 2 & Back & /bæk/ \\
\hline 3 & Good & $/ \mathrm{g} v \mathrm{~d} /$ \\
\hline 4 & Ride & /raId/ \\
\hline 5 & Pen & /pen/ \\
\hline 6 & Clock & $/ \mathrm{klpk} /$ \\
\hline 7 & Cart & /ka:rt/ \\
\hline 8 & Cod & $/ \mathrm{ka}: \mathrm{d} /$ \\
\hline 9 & $\mathrm{Cab}$ & $/ \mathrm{kæb} /$ \\
\hline 10 & Pup & $/ \mathrm{p} \Lambda \mathrm{p} /$ \\
\hline 11 & Coat & /kəut/ \\
\hline 12 & Bag & /bæg/ \\
\hline 13 & Clog & $/ \mathrm{klpg} /$ \\
\hline 14 & Pub & $/ \mathrm{p} \Lambda \mathrm{b} /$ \\
\hline 15 & Write & /rait/ \\
\hline 16 & Pig & /pig/ \\
\hline 17 & Train & /trein/ \\
\hline 18 & Pin & /pin/ \\
\hline
\end{tabular}

Table 2. Fricative error

\begin{tabular}{|c|c|c|}
\hline No & Word & Sound \\
\hline 1 & Vine & /vain/ \\
\hline 2 & Breath & /bre $\theta /$ \\
\hline 3 & Prize & /praiz/ \\
\hline 4 & Leaf & /li:f/ \\
\hline 5 & Three & /Ori:/ \\
\hline 6 & Price & /prais/ \\
\hline 7 & Path & $/ p a: \theta /$ \\
\hline 8 & Thirst & $/ \theta 3: s t /$ \\
\hline 9 & Shoe & / Ju:/ \\
\hline 10 & Ship & $/ \int \mathrm{Ip} /$ \\
\hline 11 & That & /ðæt/ \\
\hline 12 & Vote & /vəut/ \\
\hline 13 & Death & $/ \operatorname{de} \theta /$ \\
\hline 14 & Leave & /li:v/ \\
\hline 15 & View & /vju:/ \\
\hline 16 & Thumb & $/ \theta \Lambda \mathrm{m} /$ \\
\hline 17 & Mouth & $/ \mathrm{mav} \theta /$ \\
\hline 18 & Sheet & $/ \mathrm{ji}: \mathrm{t} /$ \\
\hline 19 & Treasure & /'trez.ə r / \\
\hline 20 & Thin & $/ \theta \mathrm{In} /$ \\
\hline 21 & Peas & /pi:z/ \\
\hline 22 & Free & /fri:/ \\
\hline 23 & Zip & /zip/ \\
\hline 24 & Measure & /'mez.ə r / \\
\hline 25 & Heel & /hi:1/ \\
\hline 26 & They & /ðё/ \\
\hline 27 & Thursday & /'O3:z.deI/ \\
\hline 28 & She & $/ \int \mathrm{i}: /$ \\
\hline 29 & Television & /'tel.I.vi3.ən/ \\
\hline 30 & Thing & $/ \theta \mathrm{In} /$ \\
\hline 31 & There & /ðer/ \\
\hline
\end{tabular}

From the list, the researcher will categorize the errors based on each type:

\section{Plosive error}

For some students, the difficulties between fricative and plosive are strictly different. They have to blow out air in order to pronounce the words well. Differences between thick and thin sound in " $p$ " (peh) and "b" (beh) are mostly become the challenge in pronouncing the words. They have same problem, to differ the sound when the consonant is placed in the end of the words. Then, here is the table of mostly errors of pronouncing plosive words:

Table 1. P consonant

\begin{tabular}{|c|c|c|c|}
\hline No & Word & Sound & Description \\
\hline 1 & Pin & $/ \mathrm{pIn} /$ & \\
\hline 2 & Pen & /pen/ & consonant $/ \mathrm{p} /$ \\
\hline 3 & Pup & $/ \mathrm{p} \wedge \mathrm{p} /$ & $\begin{array}{l}\text { did not } \\
\text { pronounce } \\
\text { correctly by } \\
\text { the students } \\
\text { because no air } \\
\text { was blown out }\end{array}$ \\
\hline
\end{tabular}

Table 2. B consonant

\begin{tabular}{|c|c|c|c|c|}
\hline No & Word & Sound & Error & Description \\
\hline 1 & $\mathrm{Cab}$ & /kæb/ & /kep/ & The \\
\hline 2 & Pub & $/ \mathrm{p} \Lambda \mathrm{b} /$ & $\begin{array}{l}/ \mathrm{kab} / \\
/ \mathrm{p} \Lambda \mathrm{p} /\end{array}$ & $\begin{array}{l}\text { pronounced } \\
\text { it as } / \mathrm{p} / \text {. No }\end{array}$ \\
\hline & & & /pub/ & $\begin{array}{l}\text { air was } \\
\text { blown out. }\end{array}$ \\
\hline
\end{tabular}

Table 3. K consonant

\begin{tabular}{|c|c|c|c|}
\hline No & Word & Sound & Description \\
\hline 1 & Back & /bæk/ & $\begin{array}{l}\text { The } \\
\text { consonant } / \mathrm{k} /\end{array}$ \\
\hline 2 & Coat & /kəut/ & $\begin{array}{l}\text { did not } \\
\text { pronounce } \\
\text { correctly by }\end{array}$ \\
\hline 3 & Clock & $/ \mathrm{klpk} /$ & $\begin{array}{l}\text { the students } \\
\text { because no air } \\
\text { was blown out }\end{array}$ \\
\hline
\end{tabular}

Table 4. G consonant

\begin{tabular}{|c|c|c|c|c|}
\hline No & Word & Sound & Error & Description \\
\hline \multirow[t]{3}{*}{1} & & & /bek/ & The \\
\hline & Bag & /bæg/ & & consonant \\
\hline & & & $/ \mathrm{b} \Lambda \mathrm{g} /$ & /g/ did not \\
\hline 2 & Pig & /pig/ & /pık/ & correctly \\
\hline \multirow[t]{3}{*}{3} & & & & \\
\hline & Clog & $/ \mathrm{kln} \mathrm{o} /$ & /klok/ & $\begin{array}{c}\text { because it } \\
\text { was }\end{array}$ \\
\hline & Clog & / KIDg/ & / KIOK/ & $\begin{array}{c}\text { pronounced } \\
\text { as } / \mathrm{k} / . \text { It } \\
\text { should be } \\
\text { done by }\end{array}$ \\
\hline
\end{tabular}




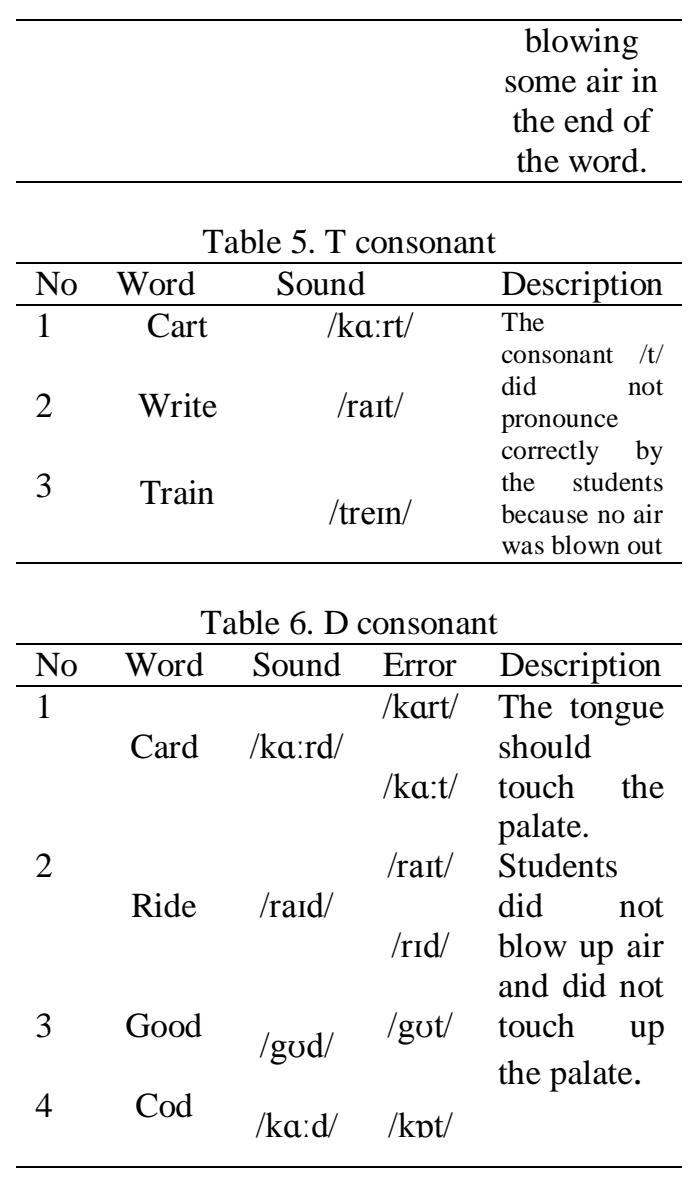

\section{Fricative error}

Table 1. Sound [s]

\begin{tabular}{|c|c|c|c|c|}
\hline No & Word & Sound & Error & Description \\
\hline 1 & Piece & /pi:s/ & $/ \mathrm{pit} \int /$ & There are \\
\hline & \multirow{6}{*}{ Price } & \multirow{6}{*}{ /prais/ } & /pais/ & that \\
\hline \multirow[t]{5}{*}{2} & & & /prait $\int$ & sometimes \\
\hline & & & I & still \\
\hline & & & & pronounce \\
\hline & & & /pris/ & with \\
\hline & & & & sound $/ \mathrm{t} \mathrm{f} /$. \\
\hline
\end{tabular}

\begin{tabular}{lcccc}
\hline No & Word & Sound & Error & Description \\
\hline 1 & Zip & /zip/ & /dzip/ & $\begin{array}{c}\text { They still } \\
\text { use the /dz/ } \\
\text { sound like } \\
\text { "jeep" to } \\
\text { pronounce } \\
\text { /zip/ and } \\
\text { also } \\
\text { still using } \\
\text { the /s/ } \\
\text { sound like } \\
\text { in "price". }\end{array}$ \\
& Peas & /pi:z/ & /priz/ & /prais/ \\
& & & /pis/ & \\
\hline
\end{tabular}

Table 3. Sound [ $]$ ]

No Word Sound Error Description

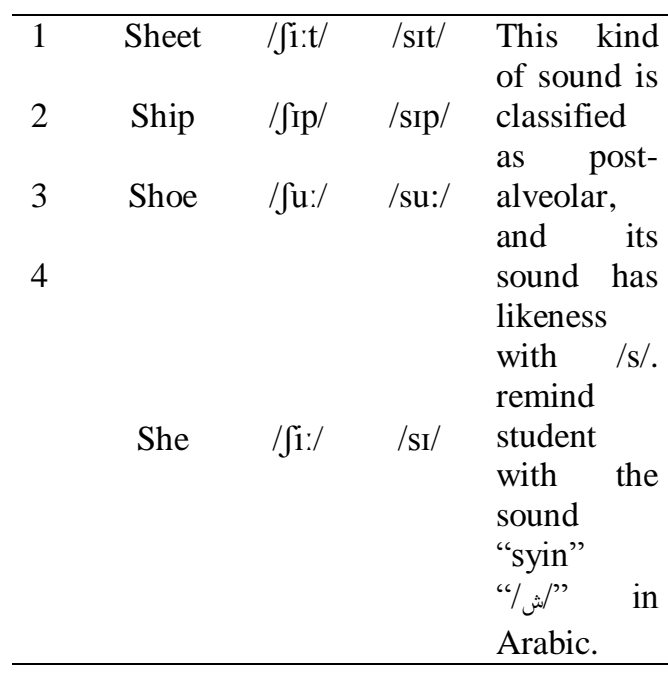

Table 4. Sound [3]

\begin{tabular}{|c|c|c|c|c|}
\hline $\begin{array}{l}\mathrm{N} \\
\mathrm{O}\end{array}$ & Word & Sound & Error & $\begin{array}{c}\text { Descript } \\
\text { ion }\end{array}$ \\
\hline \multirow[t]{8}{*}{1} & & & /'tel.e.v & $\begin{array}{l}\text { Its } \\
\text { specialty }\end{array}$ \\
\hline & & & $\mathrm{I} \int . \partial \mathrm{n} /$ & $\begin{array}{l}\text { is } \\
\text { buzzing }\end{array}$ \\
\hline & & & /'tel.e.v & $\begin{array}{l}\text { sound, } \\
\text { but most }\end{array}$ \\
\hline & Televisi & /'tel.I.v & IS. I ə & $\begin{array}{l}\text { students } \\
\text { already }\end{array}$ \\
\hline & on & I3. $ә \mathrm{n} /$ & $\mathrm{n} /$ & $\begin{array}{l}\text { mistake } \\
\mathrm{n} \text { the }\end{array}$ \\
\hline & & & /'tel.e.v & $\begin{array}{l}\text { sound as } \\
\mid \mathrm{z} / \text {. }\end{array}$ \\
\hline & & & IZ. I ə & $\begin{array}{l}\text { Almost } \\
\text { all }\end{array}$ \\
\hline & & & $\mathrm{n} /$ & $\begin{array}{l}\text { students } \\
\text { made }\end{array}$ \\
\hline 2 & Treasur & /'trez.ə & /'tre $\int . ə$ & mistakes \\
\hline
\end{tabular}

/'tres.ə

r /

I'tres. $v$

r /

/'trez.v

r/

3 Measur /'mez. /'mej.ə

e $\quad$ r/ $\mathrm{r} /$ 


\begin{tabular}{c} 
/'mez.ə \\
r/ $/$ mes.ə \\
r/ $/$ mes. \\
or / \\
\hline
\end{tabular}

Table 5. Sound [f]

\begin{tabular}{ccccl}
\hline No & Word & Sound & Error & Description \\
\hline 1 & Free & /fri:/ & /pri/ & $\begin{array}{l}\text { Only few } \\
\text { students }\end{array}$ \\
2 & Leaf & /li:f/ & $/$ lip/ & $\begin{array}{l}\text { did } \\
\text { mistakes in } \\
\text { this sound. }\end{array}$ \\
\hline
\end{tabular}

Table 6. Sound [v]

\begin{tabular}{|c|c|c|c|c|}
\hline No & Word & Sound & Error & Description \\
\hline 1 & Vine & /vain/ & $\begin{array}{l}\text { fain/ } \\
/ \text { fin/ }\end{array}$ & $\begin{array}{l}\text { This is a } \\
\text { thicker }\end{array}$ \\
\hline \multirow[t]{2}{*}{2} & Vote & /vəut/ & $\begin{array}{l}\text { /fout/ } \\
\text { /fot/ }\end{array}$ & $\begin{array}{lr}\text { version } & \text { of } \\
/ \mathrm{f} /, & \mathrm{a}\end{array}$ \\
\hline & & /vout/ & & $\begin{array}{l}\text { labiodental } \\
\text { which }\end{array}$ \\
\hline 3 & Leave & /li:v/ & /li:f/ & $\begin{array}{l}\text { means that } \\
\text { produced }\end{array}$ \\
\hline \multirow[t]{10}{*}{4} & View & /vju:/ & /fiu:/ & when lower \\
\hline & & & & $\operatorname{lip} \quad$ is \\
\hline & & & & contact \\
\hline & & & & upper teeth. \\
\hline & & & & Most \\
\hline & & & & students \\
\hline & & & & hear this as \\
\hline & & & & $\begin{array}{l}\text { /b/ but then } \\
\text { pronounced }\end{array}$ \\
\hline & & & & the sound \\
\hline & & & & as /f/. \\
\hline
\end{tabular}

Table 7. Sound [h]

\begin{tabular}{ccccl}
\hline No & Word & Sound & Error & Description \\
\hline 1 & Heel & /hi:l/ & /Il/ & Only few \\
& & & & students \\
& & & & did mistake \\
& & & & in this \\
& & & & sound. \\
\hline
\end{tabular}

Table 8. Sound $[\theta]$

\begin{tabular}{ccccc}
$\mathrm{N}$ & Word & Sound & Error & $\begin{array}{c}\text { Descript } \\
\text { ion }\end{array}$ \\
\hline
\end{tabular}

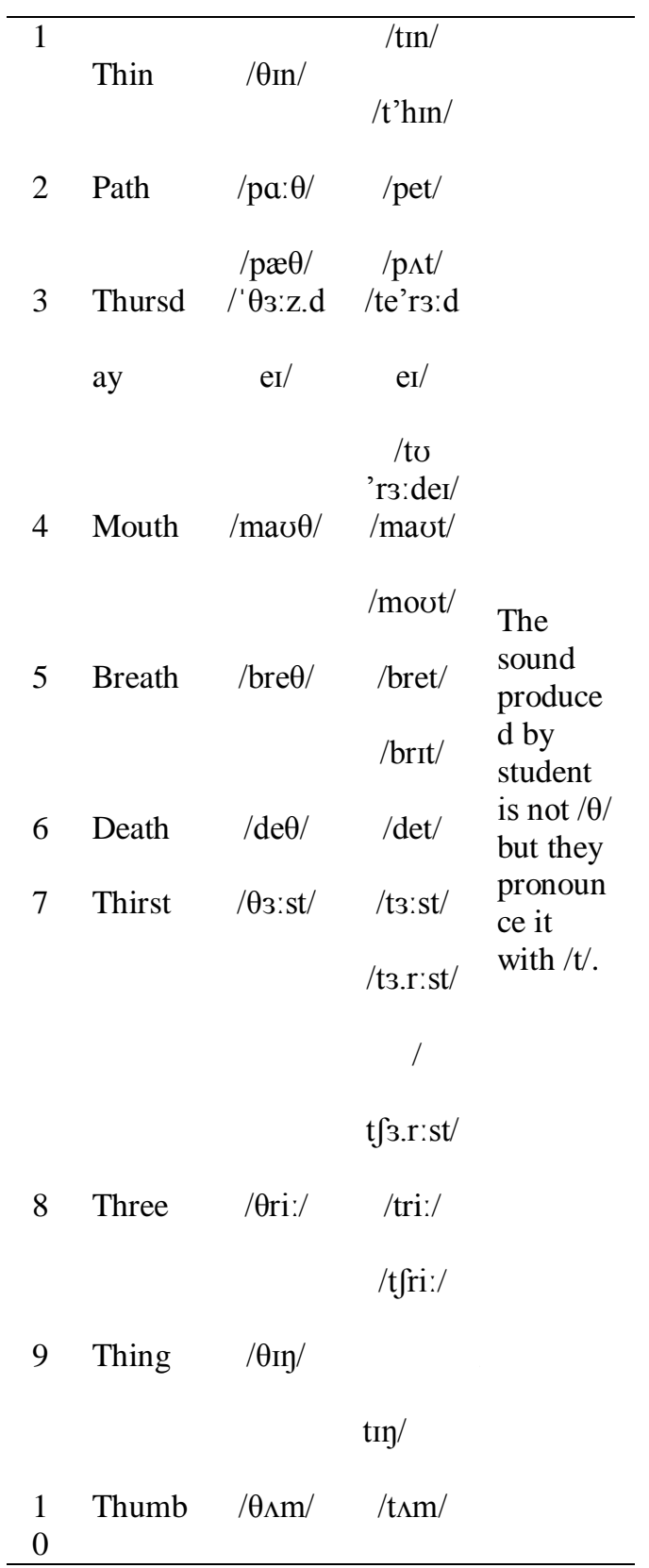

Table 9. Sound [ð]

\begin{tabular}{|c|c|c|c|c|}
\hline No & Word & Sound & Error & Description \\
\hline 1 & & & /dæt/ & \\
\hline & That & /ðæt/ & /det/ & \\
\hline 2 & They & /ðеi/ & /deI/ & $\begin{array}{l}\text { Many } \\
\text { students } \\
\text { replaced /ð/ }\end{array}$ \\
\hline 3 & There & /ðer/ & /der/ & with /d/ \\
\hline
\end{tabular}




\section{DATA ANALYSIS}

After the researcher analyzed 50 students' recordings, the researcher found the types of error that the students did and also found the most dominant error type. All of this is shown in the table below:

Table 1. Plosive error percentage

\begin{tabular}{|c|c|c|c|}
\hline $\begin{array}{l}\mathrm{N} \\
\mathrm{O}\end{array}$ & Plosive Errors & $\begin{array}{l}\text { Student' } \\
\text { s word } \\
\text { error }\end{array}$ & $\begin{array}{c}\text { The } \\
\text { errors in } \\
\text { percentag } \\
\mathrm{e}\end{array}$ \\
\hline \multirow[t]{7}{*}{1} & $\begin{array}{l}\text { Plosive sound } \\
\text { consonants }\end{array}$ & 18 & $36 \%$ \\
\hline & a. [p] & 3 & $16,6 \%$ \\
\hline & b. [b] & 2 & $11,1 \%$ \\
\hline & c. $[\mathrm{k}]$ & 3 & $16,6 \%$ \\
\hline & d. $[\mathrm{g}]$ & 3 & $16,6 \%$ \\
\hline & e. $[t]$ & 3 & $16,6 \%$ \\
\hline & f. [d] & 4 & $22,2 \%$ \\
\hline
\end{tabular}

Table 2. Fricative error percentage

\begin{tabular}{lccc}
\hline $\begin{array}{l}\mathrm{N} \\
\mathrm{o}\end{array}$ & $\begin{array}{c}\text { Fricative } \\
\text { Errors }\end{array}$ & $\begin{array}{l}\text { Student' } \\
\text { s word } \\
\text { error }\end{array}$ & $\begin{array}{c}\text { The } \\
\text { errors in } \\
\text { percentag } \\
\text { e }\end{array}$ \\
\hline Fricative & & \\
1. & sound & 32 & $64 \%$ \\
consonants & & \\
a. & {$[\mathrm{s}]$} & 2 & $6,25 \%$ \\
b. & {$[\mathrm{z}]$} & 3 & $9,37 \%$ \\
c. & {$[\mathrm{C}]$} & 4 & $12,5 \%$ \\
d. & {$[3]$} & 3 & $9,37 \%$ \\
e. & {$[\mathrm{f}]$} & 2 & $6,25 \%$ \\
f. & {$[\mathrm{v}]$} & 4 & $12,5 \%$ \\
g. & {$[\mathrm{h}]$} & 1 & $3,12 \%$ \\
h. & {$[\theta]$} & 10 & $31,25 \%$ \\
& & & \\
\hline
\end{tabular}

\begin{tabular}{llll}
\hline i. & {$[ð]$} & 3 & $9,37 \%$
\end{tabular}

\section{CONCLUSION}

Based on the discussion on the previous chapter, there are conclusions and suggestions as result of the research will be described.

After doing the research on error analysis of pronunciation, the writer concludes that the students' most pronunciation errors occur on pronouncing " $[\theta]$ ". The students do errors of pronouncing fricative consonants because they are not familiar on how they should pronounce.

The causes of students' pronunciation errors are the different sound between English and Indonesian. They did not get enough practices on phonology. It may because they did not familiar with true English pronunciation since they were young. In fact, the total pronunciation mindset they had were from television and songs.

Although some researchers believe that all learners have the same capacity to learn a second or foreign language because they have learned their first language, a number of EFL teachers have difficulties in improving the students' pronunciation problems.

There are a significant number of strategies for English pronunciation instruction that can help learners meet their personal and professional needs. They are to identify specific pronunciation features that cause problems for learners, make learners aware of the prosodic features of language (stress, intonation, rhythm), and focus on developing learners' communicative competence.

The learners' motivation can be seen the strongest factor contributing to the success or failure of learning a second or foreign language. That is, it is a driving force encouraging a learner to pursue a course of action, initiating the learning, and finally sustaining the learning process (Dörnyei, 2001:3). Basically, if the learners' motivation is high, then they will be willing to improve their abilities by themselves. On the other hand, if they do not see the value or pay attention to their pronunciation, they may not be motivated to do well. 


\section{REFERENCES}

Arikunto, S. 1990. Manajemen Penelitian, Jakarta, PT. Rineka Cipta

Avery, P. \& Ehrlich, S. (1987). Preliminary Considerations In The Teaching $O f$ Pronunciation. London: TESL Center.

Celce-Murcia, M., Brinton, D., \& Goodwin, J. (2000). Teaching Pronunciation: A Reference For Teachers of English To Speakers Of Other Languages. Cambridge: Cambridge University Press

Cohen, L. et al. 2007. Research Methods in Education Sixth Edition. London and New York:Routledge

Creswell, J. W. 2012. Educational Research $4^{\text {th }}$ Edition. Ohio:Person Merrill Prentice Hall

Crystal, D. 2003. The Cambridge Encyclopedia of the English Language.2nd ed. Cambridge: Cambridge University Press.

Dörnyei, Z. (2001). Teaching And Researching Motivation. Harlow: Longman.Inc, Englewood Cliffs.

Erdogan, V. 2005. Contribution of Error Analysis to Foreign Language Teaching. . Retrivied on June, 2014 from

Http://efd.mersin.edu.tr/dergi/meuef d/.pdf

Hasyim, S. 2002. Error Analysis in the Teaching of English. Journal'Kata'. No 1. Page 42-50. Retrieved on June 2014 from http://puslit.petra.ac.id/journal/letter s/

Haymes, J. (2000). The Development of Interactive Oral Proficiency In The Classroom. Retrieved on June 10, 2014 from:

http://www.developingteachers.com/articles _tchtraining/orprof1_jake.htm

Indriani, M.I. 2005. English Pronunciation : the English Speech Sounds Theory and Practice. Jakarta : Gramedia
James, C. 2013. Errors in Language Learning and Use. New York. Routledge

James, L. and Smith, O. 2007. Get Rid of Your Accent. London:Business and Technical Communication Services Limited.

\section{BIOGRAPHY}

Febby Pratama Putra was born in Lamongan on February $11^{\text {th }} 1988$. His bachelor's degree (S.S) was obtained in Nusa Mandiri Jakarta, and he finished his master's degree (M.Pd) in Indraprasta PGRI University. Now, he is a permanent lecturer in Indraprasta PGRI University since 2018. 